\title{
437 全身用骨密度測定装置（DEXA）における被曝線量の検討
}

A study of exposure dose useing whole body DEXA unit

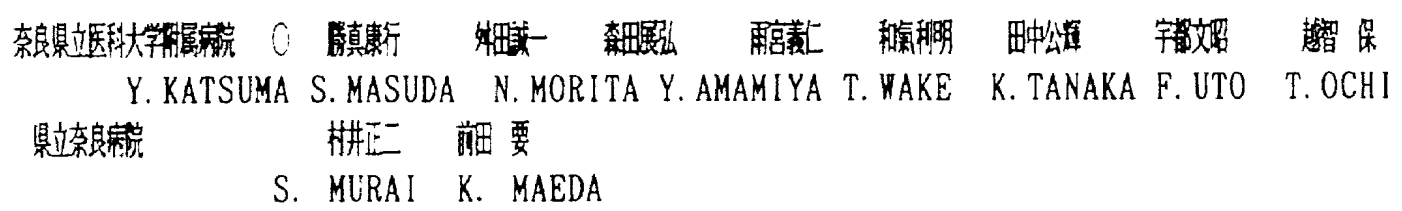

【目的】最近急速に普及してきたデュアルエネルギーX線吸収湖定法による骨密度測 定装置について被曝線量を測定し、一般撮影領域の被懪線量と比較検討する。 【使用機器】

骨密度測定装置 HOROGIC QDR-2000 以下、DEXAと各す。

電離箱線量計 IONEX 2500/3、PTW-W23361 電離容積 $30 \mathrm{C} \mathrm{c}$ 電総研校正済み 熱営光線量計 HARSHAW3500型 TLD素子 $\left(\mathrm{AL}_{2} \mathrm{O}_{3}\right)$ 以下、TLD線量計と略す。 一般撮影装置 SIMADZU UD150B-10 0.2/0.8P39CK-100 ファントム paraffin

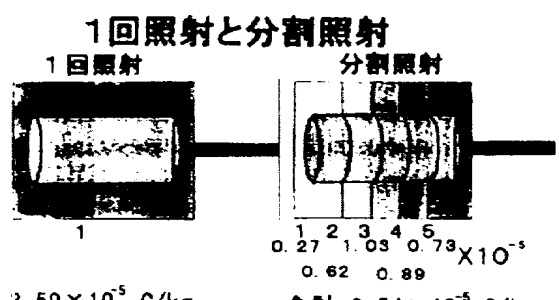

【はじめに】

・DEXAは、吅ーピームのX線を用いているため、電噰箱楾量計のチェングーを一度 に照射できないため、一般撮影装置にてチェンハー1回照射と分郜照射の合計の 線量を比較した結果 1 回照射 $35.9 \mu \mathrm{C} / \mathrm{kg}$ 、分割照射合計 $35.4 \mu \mathrm{C} / \mathrm{kg}$ 、となり ほぼ同し値を示した。（図 1)

・DEXAは70kVと140kVのX線が空気、7クル、アパタイを透過して照射される為 それぞれを分離して測定する事が出来ないため、今回は 1 つの連続X線と 扱い半価層法にて実効工杖” $-(50.1 \mathrm{keV})$ を求め、電能箱線量計の校正定数 1.61 とTLD線量計のエネ代・特性2.17を導いた。

[実験方法】

・DEXAの線量測定を図にに示すように、テープル上にファントムを設置し(図2)、 患者皮層表面を想定した吸收線量の测定を腰椎正面测定モード4つ(表1)に ついて行い比較した。

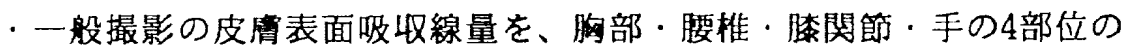
正面撮影条件(表2)にて测定し、DEXAと比較した。

【結果】

・電離箱線量計を用いて如ーピームを测定する場合、同一線量染で線量計 全体をスキャンすれば誤差の少ない湖定結果が得られた。

・DEXAの测定モート・によって電離箱線量計の测定值は、TLD線量計の4 $4 \%$ 增となった。(表3)

・DEXAの測定モートにによって皮唐表面吸収線量は、胸部単純撮影洔の約 1/3〜2.4倍となった。（図3）

【考察】

·今回の测定結果は、組織荷重係数を加味しない吸収線量のため、 一般に言われているDEXAの線量当量值（胸部撮影の1/10程度）之異 なったと考える。

. 2 種類の連続 X線を 1 つの連続X線として半価層法により実効工礼 ギーを求めたが、その值の信頼性については、検証する余地がある。

【まとめ】

・DEXAの皮唐表面線量は、選択するモートににおいて一般撮影より多く はることがある。よって、経過観察を要する骨密度测定は、求めら れる精度 (真值との誤差、再現性) と被曝線量を考虑し测定モードを選 択すべきである。

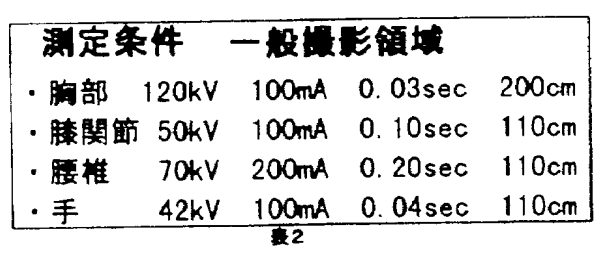

酒定モート间の比较

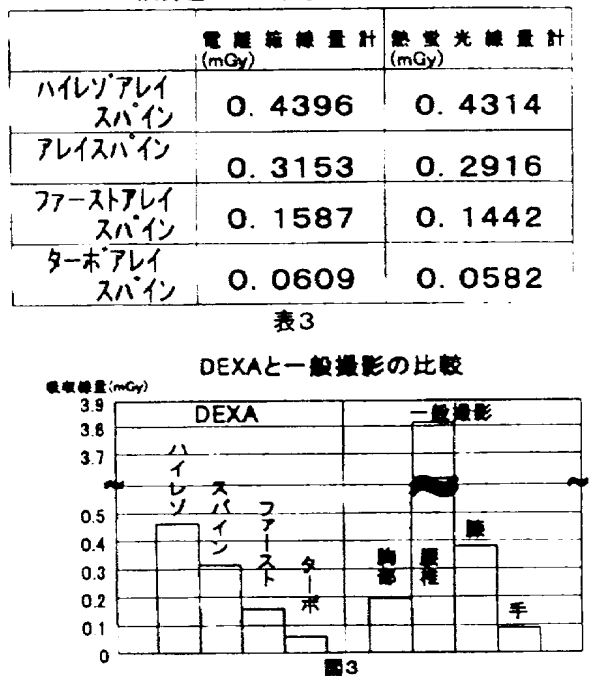

